\title{
Foreword 3
}

After the massive failures in governance during the first decade of the twenty-first century - starting with Enron, Worldcom and Parmalat and building to an impressive crescendo with the global financial crisis of 2007-2009 - this edited volume by Professors Barth, Lin and Wihlborg on banking and governance could not possibly be published at a more timely moment.

Banks matter. They mobilize resources, allocate capital, monitor the use of that capital, provide risk management tools, and facilitate payments. When banks do their jobs well, societies benefit as credit flows to those with the best entrepreneurial ideas. As a result, people enjoy faster and more inclusive economic growth. But, when banks do their jobs poorly, societies suffer as credit - and hence economic opportunity - flows to the rich and powerful rather than to the innovative and energetic. And, with poorly functioning banks, credit too frequently pours into activities that generate quick bonuses or other perquisites for bank executives at the expense of long-run economic prosperity and stability.

Since banks matter, the governance of banks matters, as the recent crisis demonstrated all too well. Many economists and policymakers assumed that privately owned financial institutions would look after their own interests and in the process help society. But this view is based on the belief that those making decisions for the financial institutions are maximizing shareholder value. That is, this free-market approach assumes financial institutions are well governed. However, rather than maximizing the value of the institution to shareholders, executives maximized the value of the financial institution to executives, which often deviated wildly from the goals of shareholders. Executives used their influence over the board of directors to obtain enormous bonuses regardless of long-run performance. Indeed, some received lavish compensation despite the wretched performance of the financial institutions under their charge. Shareholders were simply unable to force financial institution executives to behave in the best interests of shareholders. The crisis cannot be understood without recognizing the breakdown in governance.

What accounts for the breakdown in the governance of the financial system? Diffuse shareholders and creditors have a hard time influencing what happens inside firms, and banks are particularly difficult for outsiders to influence because of their opacity. Although information problems are present in all sectors, they are particularly acute in finance. For example, consider sales as an indicator of quality. If Apple sells lots of iPods over a few years, this is a reasonable signal of the product's quality. But if a bank makes lots of loans over a few years, this does not necessarily provide accurate information about the quality of those loans. It is exceptionally difficult to discern the value of financial instruments and hence the quality of the financial firms holding those securities. Thus, the opacity of financial firms hinders effective governance. Since investors cannot easily figure out the condition and activities of financial firms, insiders - executives and large shareholders - can more easily exploit other investors and use the firm to achieve their own ends. 
This challenge - addressing governance problems in finance that have been enormously costly to shareholders and taxpayers - is the focus of this volume. Private markets do not effectively govern financial intermediaries. This deficiency in private governance arises both because of market failures and because of bad policies and regulations that dissuade private investors from energetically monitoring the activities of financial institutions. Thus, the volume examines the role of financial policies and regulations in fostering better governance of financial institutions. The present volume excels at laying out the issues that affect both private and official governance of financial intermediaries, covering the existing literature and offering new perspectives.

Alas, who governs the financial regulators - the Guardians of Finance? Just as there are consequential challenges associated with designing policies, regulations and laws that induce the executives of financial institutions to behave in the best interests of shareholders rather than in the narrow, private interests of the executives, there are serious challenges associated with designing institutions to compel the Guardians of Finance, such as the Federal Reserve, the Securities and Exchange Commission and the Federal Deposit Insurance Corporation, to behave in the best interests of the public rather than in the narrow, private interests of individual regulators. Just as sound governance of banks is crucial for getting well-functioning banks, sound governance of the regulators is crucial for getting sound financial sector policies.

As we, along with Jim Barth, show in Guardians of Finance: Making Regulators Work For Us (MIT Press, 2012), the most recent and earlier crises were marked by regulators failing to act in the public interest. As with governing banks, the problem is that the insiders have much greater information than outsiders, where the outsider in the case of regulation is the public. Regulators have access to confidential information, and it is hard for the public or legislators to know what regulators knew and when they learned it. And regulation is extraordinarily complex, so it is difficult for a public with limited information to assess the quality of bank regulation. Just as the amount of loans is a poor metric of the quality of banking services, so the number of regulations, regulatory bodies and regulators is a poor signal of the quality of financial regulation.

In sum, governance mechanisms in finance need a careful rethinking. This volume represents a valuable contribution to this process. As we continue, we would stress that good governance is so important in finance that the governance of the financial regulatory agencies themselves should be an integral part of this rethinking.

Gerard Caprio

William Brough Professor of Economics and Chair, Center for Development Economics, William College Williamstown, MA, USA

Ross Levine James and Merryl Tisch Professor of Economics and Director, William R. Rhodes Center for International Economics and Finance, Brown University Providence, RI, USA and the NBER 
Gerard Caprio and Ross Levine - 9781849806107 Downloaded from PubFactory at 04/26/2023 12:34:13PM 